Issue 3 (September, 2015)

\title{
Implementasi Customer Relationship Management (CRM) Terhadap Kepuasan dan Loyalitas Pelanggan Pengguna Smartphone Android Merek Samsung
}

\author{
Luli Yulianti1), Herman Sjahruddin²), Bungatang Tahir ${ }^{3}$ ) \\ ullaulhie@gmail.com \\ 1) Mahasiswa Program Studi Manajemen pada Sekolah Tinggi Ilmu Ekonomi Bongaya \\ Makassar \\ 2,3) Dosen Program Studi Manajemen pada Sekolah Tinggi Ilmu Ekonomi Bongaya \\ Makassar
}

\begin{abstract}
ABSTRAK
Studi ini menguji pengaruh customer relationship management terhadap kepuasan, tujuan kedua adalah untuk menguji dan menganalisis pengaruh customer relationship management terhadap loyalitas, ketiga adalah untuk menguji dan menganalisis pengaruh kepuasan terhadap loyalitas pelanggan dan yang keempat adalah Untuk menguji dan menganalisis pengaruh customer realtionship management pada loyalitas melalui kepuasan sebagai variabel mediasi pada pengguna smartphone samsung merek samsung studi pada PT. Erafone di Makassar. Populasi dalam penelitian ini adalah pengguna smartphone samsung merek samsung pada pengunjung PT. Erafone. di Makassar Sampel berjumlah 82 responden. Analisis penelitian dilakukan dengan menggunakan analisis jalur dengan program aplikasi statistic SPSS versi 21.0 untuk pengelolahan data. hasil analisis deskriptif menunjukkan: a) indikator Tekhnologi yang paling dominan dalam variabel Customer reklationship management b) indkator harapan (expectation) adalah yang paling dominan dalam variable kepuasan c) indikator repeat purchasing (pembelian ulang) yang paling dominan dalam variabel loyalitas. Hasil pengujian hipotesis adalah: 1) variabel customer relationship management (X) mempunyai pengaruh signifikan terhadap variabel kepuasan (Y1), 2) variabel customer relationship management $(\mathrm{X})$ tidak berpengaruh terhadap variabel loyalitas, 3) variabel kepuasan berpengaruh signifikan terhadap loyalitas
\end{abstract}

Kata kunci: Customer relationship management, kepuasan, loyalitas, pelanggan

\section{A. Latar Belakang}

Saat ini persaingan dalam dunia bisnis terasa semakin ketat, hal tersebut juga dapat dirasakan di Indonesia, terutama dalam bidang tekhnologi telekomunikasi. Kebutuhan akan alat komunikasi seperti telepon seluler (handhphone) atau Smartphone selalu mengalami peningkatan dari tahun ketahun terutama untuk jenis-jenis handhphone atau Smartphone dengan merek-merek tertentu (Harjasiswi dan Yuliati, 2014:86). Produsen telepon genggam di dunia bahkan di Indonesia sendiri, saat ini sudah tidak terhitung jumlahnya. Semakin banyak produsen yang memproduksi barang serupa, maka semakin ketat persaingannya. Hal ini dikarenakan pola konsumsi konsumen pada saat ini yang selalu menginginkan sebuah kemudahan dalam komunikasi yang dapat mendukung 


\section{JURNAL ORGANISASI DAN MANAJEMEN}

Issue 3 (September, 2015)

kegiatan mereka sehari-hari baik dalam bidang pekerjaan maupun hal yang lainnya (Maulidiyah, 2012).

Perkembangan dunia pemasaran dan persaingan yang semakin ketat, berakibat pada banyaknya perusahaan yang tidak lagi memfokuskan aktivitas pemasaran semata-mata pada pencarian pembeli baru, namun sudah lebih kepada usaha mempertahankan dan meningkatkan kesetiaan pelanggan lama (Febriyan dan Sulistyowaty, 2014:51). Hal ini mempertegas pernyataan yang menyatakan bahwa biaya untuk memperoleh pembeli baru dapat lima kali lebih mahal dibandingkan dengan biaya yang digunakan untuk mempertahankan pelanggan lama (Shoemaker dan Lewis; dalam Wijaya dan Thio, 2008:2). Bahwa dengan menjalin hubungan dengan pelanggan atau Customer Relationship Management merupakan salah satu upaya untuk mempertahankan dan menumbuhkan basis pelanggan yang loyal. Penjelasan yang mendasari terbentuknya pengaruh manajemen hubungan pelanggan (customer relationship management) mengacu dari teori diskonfirmasi harapan (expectancy-disconfirmation theory) yang menjelaskan bahwa pelanggan membeli barang dan jasa dengan harapan pada saat pra-pembelian dilakukan penilaian kinerja dari barang maupun jasa yang telah dibeli oleh pelanggan. Setelah produk atau jasa yang telah dibeli dan digunakan, hasilnya dapat dibandingkan dengan harapan (ekspektasi) pelanggan, jika hasilnya sesuai harapan pelanggan berarti telah terjadi konfirmasi. Sedangkan Diskonfirmasi terjadi ketika ada perbedaan antara harapan dan hasil. Kepuasan disebabkan oleh konfirmasi atau diskonfirmasi positif dari harapan (ekspektasi) dan ketidakpuasan disebabkan oleh diskonfirmasi negatif dari harapan pelanggan (Oliver, 1980; dalam Ramli dan Sjahruddin, 2015).

Berdasarkan teori tersebut dapat dijelaskan bahwa terdapat beberapa faktor yang mempengaruhi loyalitas pelanggan antara lain manajemen hubungan pelanggan (Customer Relationship Management), atau yang disingkat dengan CRM dan Kepuasan pelanggan. bahwa loyalitas pelanggan disebabkan karena kemampuan manajemen perusahaan dalam membina hubungannya dengan pelanggan yang kemudian berdampak terhadap terciptanya kepuasan yang pada gilirannnya meningkatkan loyalitas pelanggan dalam menggunakan produk atau jasa yang dihasilkan perusahaan (Febrianingtyas, dkk., 2014:2). Pernyataan tersebut sesuai dengan pandangan yang mengemukakan bahwa Loyalitas pelanggan berawal dari pelayanan perusahaan yang memuasakan sehingga menghasilkan kepuasan pelanggan. Kepuasan pelanggan adalah membandingkan antara kinerja yang dirasakan dengan yang diharapakan (Kotler, 2007).

Salah satu upaya yang dilakukan perusahaan untuk mendapatkan pelanggan yang loyal adalah dengan menerapkan Customer Relationship Management (CRM). CRM merupakan suatu proses mendapatkan, mempertahankan, dan mengembangkan pelanggan yang menguntungkan dan memerlukan suatu fokus yang jelas terhadap atribut suatu jasa yang dapat menghasilkan nilai kepada pelanggan sehingga dapat menghasilkan loyalitas (Gaffar, 2007:87). Pengukuran yang digunakan dalam menjelaskan CRM terdapat empat pengukuran yaitu; (1) teknologi, (2) proses, (3) data dan informasi, (4) manusia (sumber daya manusia) (Gordon, 2002; dalam Imasari dan Nursalin 2011:185).

Bukti empiris yang menunjukkan adanya pengaruh CRM terhadap loyalitas ditunjukkan dalam penelitian Imasari dan Nursalin (2011), bahwa CRM berpengaruh positif dan signifkan terhadap loyalitas. Temuan tersebut tidak didukung dengan bukti yang menunjukkan bahwa CRM berpengaruh negatif dan

Halaman 2

Author : Luli Yulianti (September, 2015). 01-13

https://dx.doi.org/10.17605/OSF.IO/DVB48 


\section{JURNAL ORGANISASI DAN MANAJEMEN}

Issue 3 (September, 2015)

tidak signifikan terhadap loyalitas konsumen (Ersi dan Semuel, 2014). Variabel lain yang mempengaruhi loyalitas pelanggan, salah satunya adalah kepuasan pelanggan. Tujuan diterapkannya konsep Customer Relationship Management ini untuk mencapai kepuasan konsumen. Konsumen yang puas akan melakukan pembelian ulang pada produk perusahaan. Kepuasan yang terjadi terus menerus dapat mewujudkan loyalitas. Kepuasan tidak selamanya dapat diukur hanya dengan harga, tetapi lebih didasarkan pada pemenuhan perasaan tentang apa yang diharapkan oleh seorang pelanggan). Bahwa pada dasarnya kepuasan adalah perasaan senang seseorang yang muncul setelah membandingkan antara persepsi atau kesannya terhadap kinerja (atau hasil) dari suatu produk dan harapan-harapannya (Kotler, 2007: 42). Pengukuran yang digunakan dalam menganalisis kepuasan pelanggan meliputi : (1) pengalaman (experience), (2) harapan (expectation) dan (3) keseluruhan (overall satisfaction) (Tjiptono, 2006).

Bukti empiris yang menunjukkan pengaruh CRM terhadap kepuasan ditunjukkan dalam penelitian (Bhaskara dkk., 2014) yang membuktikan bahwa CRM berpengaruh parsial terhadap kepuasan pelanggan. Faktor lain selain kepuasan adalah loyalitas pelanggan yang merupakan komitmen pelanggan terhadap suatu merek, toko, pemasok, berdasarkan sikap positif yang tercermin dalam pembelian ulang yang konsisten, loyalitas pelanggan akan berpengaruh terhadap kelangsungan hidup perusahaan, dimana perusahaan bertahan karena produk atau jasa yang digunakan terus-menerus oleh pelanggan (Tsiros et al., 2004:155). Pengukuran loyalitas dicerminkan melalui; (1) Pemberian rekomendasi (Word of mouth), (2) kesetiaan produk (Reject another), dan (3) pembelian ulang (Repeat purchasing), (Kotler dan Keller, 2006;57). Hasil temuan peneliti terdahulu membuktikan bahwa hubungan antara variabel kepuasan secara keseluruhan berpengaruh positif dan signifikan terhadap loyalitas (Febrianingtyas dkk., 2014).

Samsung Electronics Co, Ltd. adalah perusahaan elektronik dan teknologi informasi multinasional yang bermarkas di Suwon Korea Selatan. Perusahaan ini merupakan anak perusahaan Samsung Group dan telah menjadi perusahaan Information and technologi (IT) dengan pendapatan terbesar di dunia sejak 2009. Samsung elektronik adalah produsen Smartphone/gadget (Smartphone) terbesar kedua di dunia setelah Intel Corporation. Keberadaan produk Smartphone Samsung sampai dengan sekarang dikenal dan mendominasi pangsa pasar produk Smartphone/gadget (Smartphone) dengan merek Samsung Galaxy S5 dan Galaxy Alpha dan sebagainya.

Fenomena Smartphone Samsung berbasis sistem operasi android belakangan ini menjadi trend di Indonesia, sehingga menjadi suatu kebutuhan tidak hanya sebagai pelengkap gaya hidup, tetapi juga sebagai kebutuhan dalam membantu kegiatan kantor dan bisnis serta aktivitas lainnya, selain itu pertumbuhan pengguna Smartphone merek Samsung berbasis sistem operasi android di Indonesia semakin meningkat. Kondisi ini melatar belakangi peneliti untuk menganalisis faktor-faktor yang menjadi pertimbangan konsumen dalam memutuskan untuk membeli Smartphone merk Samsung bersistem operasi Android.

Berdasarkan data yang diperoleh, ditunjukkan penjualan produk Smartphone dari beberapa pabrikan pada Tabel berikut: 
Issue 3 (September, 2015)

Tabel 1. Global Smartphone Vendors, Shipments, Market Share, Year-Over-Year Growth per Kwartal Tahun 2015

Global Smartphone vendor

shipments (millions of units)

Samsung

Apple

Lenovo-Motorolla

Huawei

Others

Total

Global Smartphone vendor

Marketshare (millions of units)

Samsung

Apple

Lenovo-Motorolla

Huawei

Others

Total

\begin{tabular}{|c|c|c|c|c|}
\hline $\mathbf{Q 1} 14$ & $\mathbf{Q 2} 14$ & $\mathbf{Q 3} \mathbf{1 4}$ & $\mathbf{Q 4} \mathbf{1 4}$ & $\mathbf{Q 1} \mathbf{1 5}$ \\
\hline 89.0 & 74.5 & 79.2 & 74.5 & 83.2 \\
\hline 43.7 & 35.2 & 39.3 & 74.5 & 61.2 \\
\hline 19.7 & 23.8 & 24.5 & 24.7 & 18.8 \\
\hline 13.4 & 20.1 & 16.5 & 24.1 & 17.3 \\
\hline 119.2 & 141.4 & 163.9 & 182.3 & 164.5 \\
\hline 285.0 & 295.0 & 323.4 & 380.1 & 345.0 \\
\hline & & & & \\
\hline Q1'14 & Q2'14 & Q3'14 & Q4'14 & Q1'15 \\
\hline $31.2 \%$ & $25.3 \%$ & $24.5 \%$ & $19.6 \%$ & $24.1 \%$ \\
\hline $15.3 \%$ & $11.9 \%$ & $12.2 \%$ & $19.6 \%$ & $17.7 \%$ \\
\hline $6.9 \%$ & $8.1 \%$ & $7.6 \%$ & $6.5 \%$ & $5.4 \%$ \\
\hline $4.7 \%$ & $6.8 \%$ & $5.1 \%$ & $6.3 \%$ & $5.0 \%$ \\
\hline $41.8 \%$ & $47.9 \%$ & $50.7 \%$ & $48.0 \%$ & $47.7 \%$ \\
\hline $100.0 \%$ & $100.0 \%$ & $100.0 \%$ & $100.0 \%$ & $100.0 \%$ \\
\hline
\end{tabular}

$\begin{array}{llr}\text { Year-over-Year (\%) } & \mathbf{3 3 . 2 \%} & \mathbf{2 6 . 6 \%}\end{array}$

Berdasarkan Tabel tersebut, dapat ditunjukkan bahwa vendor raksasa Smartphone Samsung menemmpati posisi pertama hingga Q1 2015 dengan jumlah 83,2 juta unit atau sebesar 24 persen dari penjualan Smartphone global. Prestasi tersebut diperoleh melalui berbagai upaya antara lain dengan menerapkan hubungan yang baik dengan pelanggan atau custumer relationship management (CRM). Fakta tersebut memotivasi peneliti untuk melakukan penelitian pada pengguna Smartphone merek Samsung berbasis android.

\section{B. Tinjauan Pustaka}

\section{Pengertian karakteristik individu}

Salah satu cara perusahaan dalam memberikan kepuasan pelanggan adalah dengan menerapkan cutomer relationship management (CRM). CRM merupakan serangkaian aktivitas yang terintegrasi dalam rangka mempertahankan dan mengembangkan pelanggan yang menguntungkan sebagai bentuk tanggung jawab perusahaan terhadap pelanggan dalam mewujudkan kepuasan pelanggan. Menurut Kotler dan Armstrong (2008:13), CRM merupakan suatu strategi dan gaya manajemen untuk membangun dan memelihara hubungan dengan pelanggan yang menguntungkan dengan memperhatikan nilai dan kepuasan pelanggan. Brown dan Rigby, Reincheld, Dawson (dalam Gaffar, 2007:87) mengungkapkan bahwa customer relationship management (CRM) merupakan suatu proses mendapatkan, mempertahankan, dan mengembangkan pelanggan yang menguntungkan dan memerlukan suatu fokus yang jelas terhadap atribut suatu jasa yang dapat menghasilkan nilai kepada pelanggan sehingga dapat menghasilkan loyalitas. Berdasarkan pengertian dari customer relationship management (CRM), bahwa CRM bukanlah suatu konsep atau proyek, melainkan suatu strategi bisnis yang bertujuan untuk memahami,mengantisipasi, dan mengelola kebutuhan pelanggan yang ada dan pelanggan potensial dari suatu organisasi.

Menurut Storbacka dan Lehitnen (dalam Gaffar, 2007:35) fokus dari customer relationship management (CRM) itu sendiri adalah untuk memperbaiki 


\section{JURNAL ORGANISASI DAN MANAJEMEN}

Issue 3 (September, 2015)

tingkat kepuasan pelanggan, meningkatkan loyalitas pelanggan dan meningkatkan pendapatan dari pelanggan yang ada, dalam menghadapi tingginya tingkat persaingan, globalisasi dan perputaran pelanggan serta perkembangan biaya pengakuisisian pelanggan. Francis Buttle (dalam Sari 2013) menyebutkan bahwa tujuan utama yang ingin dicapai oleh semua strategi customer relationship management (CRM) adalah untuk mengembangkan hubungan yang menguntungkan dengan pelanggan.

\section{Kepuasan pelanggan}

Laksana (2008:9) yang dikutip dari Kotler menyatakan bahwa kepuasan konsumen yaitu : "customer satisfaction is the outcome felt by buyers who have experienced a company performance that has fulfilled expectations". Maksudnya yaitu menyangkut komponen harapan dan kinerja/hasil yang dirasakan`. Menurut Engel, et al yang dikutip oleh Fandy Tjiptono (2008:24) menyatakan: "Kepuasan pelanggan merupakan evaluasi purna beli dimana alternatif yang dipilih sekurang-kurangnya sama atau melampaui harapan pelanggan, sedangkan ketidakpuasan timbul apabila hasil income (outcome) tidak memenuhi harapan." Selanjutnya Day dalam Tse dan Wilton yang dikutip oleh Fandy Tjiptono (2008:24) menyatakan bahwa kepuasan atau ketidakpuasan pelanggan adalah respon pelanggan terhadap evaluasi ketidaksesuaian (disconfirmation) yang dirasakan antara harapan sebelumnya (atau norma kinerja lainnya) dan kinerja aktual produk yang dirasakan setelah pemakaiannya. Beberapa definisi diatas, pada dasarnya pengertian kepuasan pelanggan mencakup perbedaan antara harapan dan kinerja atau hasil yang dirasakan (Tjiptono, 2008:24). Kepuasan tergantung pada ekspektasi pembeli yang mengekspresikan persaan kecewa bila merasa kecewa dan menimbulkan rasa puas jika produknya dirasa baik serta jika kinerja dianggap melebihi harapan pelanggan yang sangat puas.

Berdasarkan pendapat para ahli maka dapat disimpulakan bahwa dari kepuasan pelanggan adalah upaya untuk membandingkan antara kinerja atau hasil yang dirasakan dengan harapan. Apabila hasil yang dirasakan dibawa harapan, maka pelanggan akan merasa kurang puas bahkan tidak puas, namun sebaliknya bila sesuai dengan harapan

\section{Loyalitas Pelanggan}

Pelanggan (customer) berbeda dengan konsumen (consumer), dimana seseorang dikatakan sebagai pelanggan apabila orang tersebut mulai membiasakan diri untuk membeli produk atau jasa yang ditawarkan oleh suatu badan usaha. Kebiasaan tersebut dapat dibangun melalui pembelian berulang-ulalng dalan jangka waktu tertentu. Apabila dalam jangka waktu tertentu tidak melakukan pembelian ulang maka orang tersebut tidak dapat dikatakan sebagai pelanggan tetapi seorang pembeli atau konsumen (Musanto, 2004 ; dalam Giffano 2012:27).

Palmer (2006:127) menyatakan bahwa loyalitas pelanggan adalah seseorang yang beberapa kali datang ketempat yang sama untuk membeli suatu barang atau jasa untuk memenuhi apa yang diinginkan. Menurut Griffin (2005:5) menyatakan bahwa konsep loyalitas pelanggan lebih banyak dikaitkan dengan perilaku (Behavior) daripada dengan sikap. Bila seseorang merupakan pelanggan loyal, ia menunjukkan perilaku pembelian yang didefinisikan sebagai pembelian nonrandom yang diungkapkan dari waktu ke waktu oleh beberapa unit pengambilan keputusan. Sukses tidaknya suatu perusahaan dalam menciptakan pelanggan yang loyal sangat

Halaman 5

Author : Luli Yulianti (September, 2015). 01-13

https://dx.doi.org/10.17605/OSF.IO/DVB48 


\section{JURNAL ORGANISASI DAN MANAJEMEN}

Issue 3 (September, 2015)

tergantung pada kemampuan perusahaan dalam menciptakan nilai dan secara terus menerus berupaya mem-perbaikinya. Loyalitas pelanggan secara umum dapat diartikan seagai kesetiaan seseorang atas suatu produk, baik barang maupun jasa tertentu.

\section{Metode Penelitian}

Pendekatan yang dilakukan dalam penelitian ini adalah pendekatan kuantitatif melalui explanatory survey yaitu penelitian yang mengambil sampel dari suatu populasi yang diteliti dan menjelaskan hubungan klasual antara variabelvariabel yang akan melalui pengujian hipotesis. Penelitian ini menggunakan pendekatan kuantitatif yang datanya berwujud pada bilangan (angka-angka) dan pembuktian hipotesis yang dilakukan menggunakan analisis statistik (Sugiyono, 2013:13). Populasi dalam penelitian ini yaitu pengguna Smartphone android Samsung pada pengunjung PT. Erafone di Makassar yang jumlahnya sangat banyak dan tidak teridentifikasi (unidentified). dikarenakan jumlah populasi yang sangat besar dan tidak dapat di identifikasi maka penentuan sample dilakukan dengan cara menggunakan insidental sampling.

Teknik analisis data yang digunakan dalam penelitian ini, menggunakan analisis jalur. Analisis jalur adalah suatu teknik untuk menganalisis hubungan sebab akibat yang terjadi pada regresi berganda jika variabel eksogennya (independen) mempengaruhi variabel endogen (dependent) tidak hanya secara langsung, tetapi juga secara tidak langsung, yang terdiri atas pengaruh langsung dan tidak langsung. Untuk mendapatkan nilai pengaruh langsung dan tidak langsung digunakan analisis regresi dengan variabel intervening (Robert D. Rutherford; dalam Jonathan Sarwono, 2007:1).

\section{Hasil Penelitian}

1. Karakteristik responden

a) Tingkat pengembalian kuesioner

Kuesioner yang didistribusikan sebanyak 100 kuesioner, berikut ini menggambarkan tingkat pengembalian dan pengolahan kuesioner dalam penelitian ini.

Tabel 2. Tingkat pengembalian dan olah kuesioner

\begin{tabular}{|c|l|c|c|l|}
\hline No. & \multicolumn{1}{|c|}{ Keterangan } & Jumlah & Presentase & \multicolumn{1}{|c|}{ Total } \\
\hline 1 & $\begin{array}{l}\text { Jumlah kuesioner yang } \\
\text { kembali }\end{array}$ & 100 & $100 \%$ & $\begin{array}{l}\text { Total penyebaran } 100 \\
\text { kuesioner }\end{array}$ \\
\hline 2 & $\begin{array}{l}\text { Jumlah kuesioner yang } \\
\text { dapat diolah }\end{array}$ & 82 & $82 \%$ & $\begin{array}{l}\text { Total pendistribusian } \\
100 \text { kuesioner }\end{array}$ \\
\cline { 1 - 3 } & $\begin{array}{l}\text { Jumlah kuesioner yang } \\
\text { cacat }\end{array}$ & 18 & $18 \%$ & \\
\hline
\end{tabular}

Sumber : Data diolah dari hasil penelitian (2015)

Berdasarkan 100 kuesioner yang disebarkan dan yang kembali sebanyak $100 \%$ atau 100 kuesioner. Kuesioner yang dapat diolah sebanyak $82 \%$ atau 82 kuesioner. Kuesioner yang tidak dapat diolah karena tidak memenuhi kriteria sebagai sampel dan tidak diisi secara lengkap oleh responden sebanyak $18 \%$ atau 18 kuesioner. Responden dalam penelitian ini adalah penggunjung PT. Erafone yang menggunakan Smartphone merek Samsung berbasis Android. Responden penelitian

Halaman 6

Author : Luli Yulianti (September, 2015). 01-13

https://dx.doi.org/10.17605/OSF.IO/DVB48 


\section{JURNAL ORGANISASI DAN MANAJEMEN}

Issue 3 (September, 2015)

ini terdiri dari jenis kelamin, umur, pekerjan dan lamanya responden menggunakan Smartphone merek Samsung berbasis Android.

b) Distribusi responden berdasarkan jenis kelamin

Gambar berikut ini menyajikan hasil uji deskripsi responden berdasarkan jenis kelamin yang menunjukkan bahwa 44 orang atau 54\% responden didominasi oleh jenis kelamin wanita dan sisanya sebanyak 38 orang atau $46 \%$ responden berjenis kelamin pria.

Gambar 1. Distribusi Responden Berdasarkan Jenis Kelamin
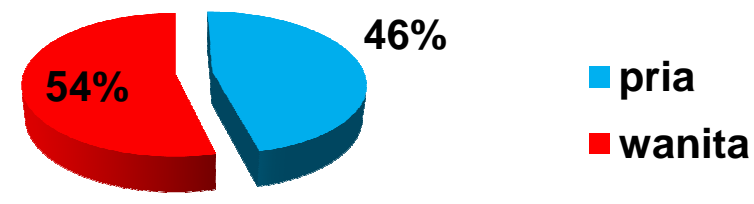

Sumber : Data diolah dari hasil penelitian (2015)

Bahwa berdasarkan faktualnya wanita lebih banyak menggunakan smartphone merek samsung dibandingkan dengan pria karena wanita cenderung lebih aktif dalam menggunakan media sosial.

c) Distribusi responden berdasarkan umur

Gambar berikut ini menyajikan hasil uji deskripsi responden berdasarkan umur yang dicirikan melalui : 15-24 Tahun sebanyak 44 orang atau sebesar 53,66\%, 25-34 Tahun sebanyak 28 orang atau sebesar 34,15\% dan 35-44 Tahun sebanyak 10 orang atau sebesar $12,20 \%$.

Gambar 2. Distribusi Responden Berdasarkan Umur

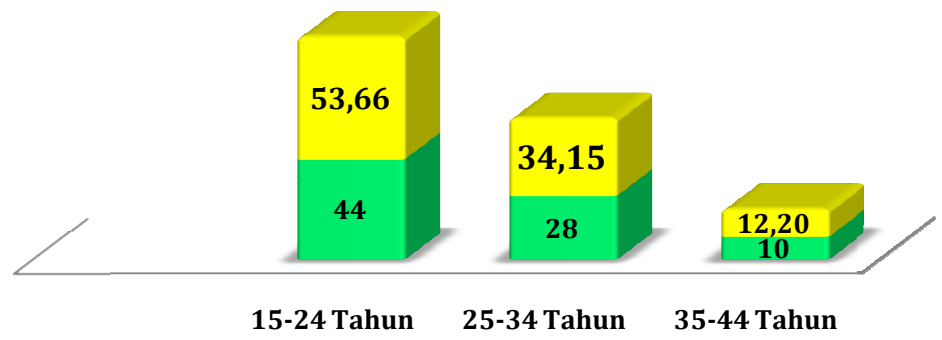

Sumber : Data diolah dari hasil penelitian (2015)

Bahwa usia 15-24 sebanyak 44 orang atau sebesar 53,66\% cenderung lebih dominan menggunakan smartphone merek samsung berbasis android, karena usia tersebut di dominasi oleh kalangan pelajar/mahasiswa, hal ini dikarenakan media sosial pada handphone/smartphone memberikan pengaruh yang sangat luar biasa terhadap kalangan pelajar. 


\section{JURNAL ORGANISASI DAN MANAJEMEN}

Issue 3 (September, 2015)

d) Distribusi responden berdasarkan lamanya menggunakan Smartphone merek samsung

Gambar berikut menyajikan hasil uji deskripsi responden berdasarkan lamanya menggunakan smartphone samsung yang dicirikan melalui : 1-5 Tahun sebanyak 46 orang atau sebesar 56\%, 3-4 Tahun sebanyak 23 orang atau sebesar $28 \%$, 5-6 Tahun sebanyak 13 orang atau sebesar $16 \%$.

Gambar 3. Distribusi Responden Berdasarkan Lamanya Menggunakan Smartphone Samsung

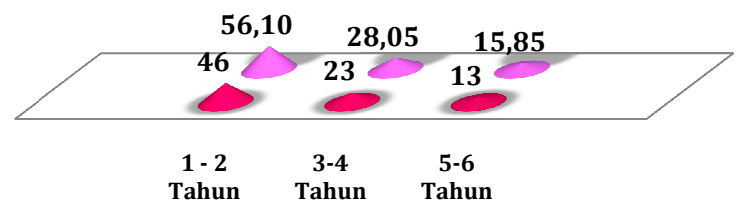

Sumber : Data diolah dari hasil penelitian (2015)

Bahwa dimana tingkat persaingan smartphone semakin tinggi sehingga banyaknya merek lainnya yang menjadi pilihan sehingga mengakibatkan menurunnya minat pengguna smartphone samsung berbasis android yang hanya kurang dari 2 tahun.

e) Distribusi responden berdasarkan pekerjaan

Gambar berikut menyajikan hasil uji deskripsi responden berdasarkan pekerjaan yang dicirikan melalui : wiraswasta sebanyak 8 orang atau 10\%, PNS sebanyak 17 orang atau 21\%, karyawan swasta sebanya 31 orang atau 31\%, dan yang terakhir pelajar/mahasiswa sebanyak 31 orang atau sebesar $38 \%$,

Gambar 4. Distribusi Responden Berdasarkan Pekerjaan
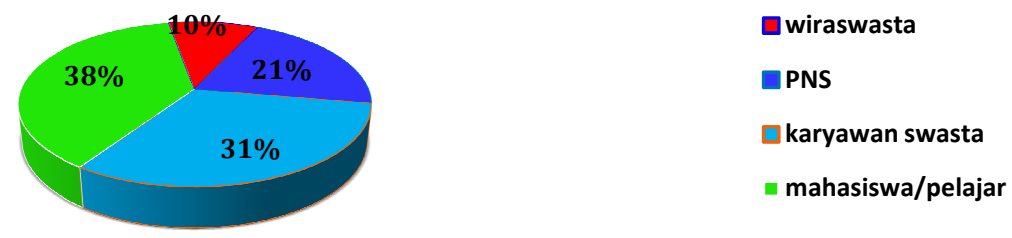

Sumber : Data diolah dari hasil penelitian (2015)

Bahwa mahasiswa/pelajar dan karyawan swasta yang lebih dominan menggunakan smartphone samsung berbasis android dikarenakan smartphone yang dilengkapi system operasi yang dapat terhubung di internet mempermudah mereka mencari informasi secara mendunia dan digunakan juga dalam kebutuhan sosial, pekerjaan dan pendidikan.

2. Deskripsi Variabel Penelitian

a. Rekapitulasi skor jawaban responden untuk variabel CRM

Author : Luli Yulianti (September, 2015). 01-13

Halaman 8

https://dx.doi.org/10.17605/OSF.IO/DVB48 


\section{JURNAL ORGANISASI DAN MANAJEMEN}

Issue 3 (September, 2015)

Tabel 3. Tanggapan Responden terhadap Variabel CRM

\begin{tabular}{|c|c|c|c|c|c|c|c|c|c|c|c|c|}
\hline \multirow[t]{3}{*}{ Indikator variabel } & \multirow{3}{*}{$\begin{array}{l}\text { (item/ } \\
\text { butir) }\end{array}$} & \multicolumn{10}{|c|}{ frekuensi jawaban responden (f) \& persentase (\%) } & \multirow{3}{*}{$\begin{array}{l}\text { Rerata } \\
\text { (mean) }\end{array}$} \\
\hline & & \multicolumn{2}{|c|}{ SS (5) } & \multicolumn{2}{|c|}{$\mathbf{s}(4)$} & \multicolumn{2}{|c|}{$\mathbf{N}(3)$} & \multicolumn{2}{|c|}{ TS (2) } & \multicolumn{2}{|c|}{ STS (1) } & \\
\hline & & $\mathbf{f}$ & $\%$ & $\mathbf{f}$ & $\%$ & $\mathbf{f}$ & $\%$ & f & $\%$ & $\mathbf{f}$ & $\%$ & \\
\hline \multirow{3}{*}{ Tekhnologi (X11) } & $\mathbf{X 1 1 1}$ & 17 & 21,00 & 39 & 48,00 & 23 & 28,00 & 3 & 4,00 & $\mathrm{O}$ & $\mathrm{O}, \mathrm{OO}$ & 3,85 \\
\hline & $\mathbf{X 1 1 2}$ & 14 & 17,00 & 38 & 46,00 & 27 & 33,00 & 2 & 2,00 & 1 & 1,00 & 3,76 \\
\hline & \multicolumn{11}{|c|}{ Rerata indikator tekhnologi (X11) } & 3,80 \\
\hline \multirow{3}{*}{ Proses (X12) } & $\times 121$ & 22 & 27,00 & 36 & 44,00 & 20 & 24,00 & 1 & 1,00 & 1 & 1,00 & 3,91 \\
\hline & $\times 122$ & 8 & 10,00 & 47 & 57,00 & 21 & 26,00 & 5 & 6,00 & $\mathrm{O}$ & $\mathrm{O}, \mathrm{OO}$ & 3,70 \\
\hline & \multicolumn{11}{|c|}{ Rerata indikator proses (X12) } & 3,80 \\
\hline \multirow{3}{*}{$\begin{array}{c}\text { Data dan Informasi } \\
(\times 13)\end{array}$} & $\times 131$ & 9 & 11,00 & 44 & 54,00 & 25 & 30,00 & 3 & 4,00 & $\mathrm{O}$ & $\mathrm{O}, \mathrm{OO}$ & 3,71 \\
\hline & $\times 132$ & 6 & 7,00 & 21 & 26,00 & 37 & 45,00 & 14 & 17,00 & 2 & 2,00 & 3,16 \\
\hline & \multicolumn{11}{|c|}{ Rerata indikator data dan informasi (X13) } & 3,43 \\
\hline \multirow{3}{*}{ Manusia (X14) } & $\mathbf{X 1 4 1}$ & 12 & 15,00 & 34 & 41,00 & 25 & 30,00 & 4 & 5,00 & $\mathrm{O}$ & $\mathrm{O}, \mathrm{OO}$ & 3,57 \\
\hline & $\times 142$ & 6 & 7,00 & 36 & 56,00 & 24 & 29,00 & 4 & 5,00 & $\mathrm{O}$ & $\mathrm{O}, \mathrm{OO}$ & 3,63 \\
\hline & \multirow{2}{*}{\multicolumn{11}{|c|}{ Rerata indikator manusia (X14) }} & 3,60 \\
\hline \multicolumn{7}{|c|}{ Rerata variabel CRM (X1) } & & & & & & 3,66 \\
\hline
\end{tabular}

Tabel tersebut menjelaskan bahwa variabel CRM dicirikan melalui tekhnologi dengan nilai rerata tanggapan responden sebesar $3.80 \%$. kondisi tersebut disebabkan karena pernyataan di dalam indikator yaitu pengguna memperoleh kemudahan dalam mendapatkan informasi tentang produk smartphone samsung dari perusahaan melalui media elektronik/cetak \& onlline dengan nilai sebanyak 3,85\%. Rerata tanggapan responden tertinggi berikutnya ditunjukkan melalui indikator Proses sebanyak 3.80\%, hal ini dikarenakan pada pernyataan bahwa perusahaan sudah memahami keinginan dan kebutuhan pelanggan dengan melakukan kegiatan promosi baik secara langsung maupun tidak langsung konsumen dengan nilai rerata sebesar 3.91\%. Rerata tanggapan responden berikutnya ditunjukkan melalui indikator data dan informasi sebesar 3,80\% hal ini dikarenakan pada pernyataan pengguna mendapatkan informasi dari perusahaan sehubungan dengan produk smartphone samsung melalui media elektronik/cetak dengan nilai sebesar 3,71\%, hal ini dikarenakan pada pernyataan bahwa. Rerata tanggapan responden yang terendah yaitu Manusia dengan nilai sebesar 3,60\% hal ini dikarenakan pada pernyataan sales marketing memiliki kemampuan dalam menjaga hubungan dengan baik kepada customer dengan nilai sebesar 3,63\%.

b. Rekapitulasi skor jawaban responden untuk variabel Kepuasan Tabel 4. Tanggapan Responden Terhadap Variabel Kepuasan

\begin{tabular}{|c|c|c|c|c|c|c|c|c|c|c|c|c|}
\hline \multirow{3}{*}{ indikator variabel } & \multirow{3}{*}{$\begin{array}{l}\text { (item/ } \\
\text { butir) }\end{array}$} & \multicolumn{10}{|c|}{ frekuensi jawaban responden (f) \& persentase (\%) } & \multirow{3}{*}{$\begin{array}{l}\text { Rerata } \\
\text { (mean) }\end{array}$} \\
\hline & & \multicolumn{2}{|c|}{ SS (5) } & \multicolumn{2}{|c|}{ S (4) } & \multicolumn{2}{|c|}{ N (3) } & \multicolumn{2}{|c|}{ TS (2) } & \multicolumn{2}{|c|}{ STS (1) } & \\
\hline & & $\mathbf{f}$ & $\%$ & $\mathbf{f}$ & $\%$ & f & $\%$ & f & $\%$ & f & $\%$ & \\
\hline \multirow{3}{*}{$\begin{array}{c}\text { Pengalaman } \\
\text { (Experience) (Y11) }\end{array}$} & X111 & 13 & 16,00 & 51 & 62,00 & 15 & 18,00 & 3 & 4,00 & 0 & 0,00 & 3,90 \\
\hline & X112 & 24 & 29,00 & 51 & 62,00 & 6 & 7,00 & 0 & 0,00 & 1 & 1,00 & 4,18 \\
\hline & \multicolumn{11}{|c|}{ Rerata indikator Experience (X11) } & 4,04 \\
\hline \multirow{3}{*}{$\begin{array}{c}\text { Harapan } \\
\text { (Expectation) (Y12) }\end{array}$} & $\mathrm{X121}$ & 13 & 16,00 & 46 & 56,00 & 21 & 26,00 & 1 & 1,00 & 0 & 0,00 & 3,85 \\
\hline & X122 & 21 & 26,00 & 40 & 49,00 & 21 & 26,00 & 0 & 0,00 & 0 & 0,00 & 4,00 \\
\hline & \multicolumn{11}{|c|}{ Rerata indikator Expectation (X12) } & 3,93 \\
\hline \multirow{3}{*}{$\begin{array}{l}\text { Kepuasan secara } \\
\text { keseluruhan } \\
\text { (OveralSatisfactio }\end{array}$} & X131 & 17 & 21,00 & 49 & 60,00 & 14 & 17,00 & 2 & 2,00 & 0 & 0,00 & 3,99 \\
\hline & $\mathrm{X} 132$ & 9 & 11,00 & 44 & 54,00 & 27 & 23,00 & 2 & 2,00 & 0 & 0,00 & 3,73 \\
\hline & \multicolumn{11}{|c|}{ Rerata indikator Overal satisfaction (X13) } & 3,86 \\
\hline \multicolumn{12}{|c|}{ Rerata variabel Kepuasan (Y1) } & 3,94 \\
\hline
\end{tabular}

Berdasarkan tabel tersebut diatas variabel kepuasan dicirikan melalui indikator Pengalaman (experience) dengan nilai rerata tanggapan responden sebesar 4,04\%, hal ini dipengaruhi dengan pernyataan dalam indikator yaitu pengalaman selama menggunakan smartphoone samsung pengguna merasa puas terhadap layanan, kualitas, fitur \& desain produk dengan nilai rerata sebesar $4,18 \%$. 


\section{JURNAL ORGANISASI DAN MANAJEMEN}

Issue 3 (September, 2015)

Indikator tertinggi lainnya di tunjukkan melalui indikator Harapan (Expectation) dengan nilai rerata tanggapan responden sebesar 3,93\%, hal ini dipengaruhi dengan pernyataan dalam indikator yaitu produk smartphone samsung yang ditawarkan pelanggan sudah memenuhi keinginan pengguna dengan nilai sebesar 4,00\%, yang terakhir indikator kepuasan secara keseluruhan dengan nilai rerata sebesar 3,86\%, hal ini dipengaruhi dengan pernyataan dalam indikator yaitu secara keseluruhan pengguna puas dengan pelayanan, kualitas, fitur dan desain produk dengan nilai sebesar 3,99\%.

c. Rekapitulasi skor jawaban responden variabel kepuasan konsumen. Tabel 5. Tanggapan Responden Terhadap Variabel Loyalitas Pengguna

\begin{tabular}{|c|c|c|c|c|c|c|c|c|c|c|c|c|}
\hline \multirow{3}{*}{ Indikator variabel } & \multirow{3}{*}{$\begin{array}{l}\text { (item/ } \\
\text { butir) }\end{array}$} & \multicolumn{10}{|c|}{ frekuensi jawaban responden (f) \& persentase (\%) } & \multirow{3}{*}{$\begin{array}{l}\text { Rerata } \\
\text { (mean) }\end{array}$} \\
\hline & & \multicolumn{2}{|c|}{ SS (5) } & \multicolumn{2}{|c|}{$\mathbf{s}(4)$} & \multicolumn{2}{|c|}{$\mathbf{N}(3)$} & \multicolumn{2}{|c|}{ TS (2) } & \multicolumn{2}{|c|}{ STS (1) } & \\
\hline & & $\mathbf{f}$ & $\%$ & $\mathbf{f}$ & $\%$ & f & $\%$ & $\mathbf{f}$ & $\%$ & $\mathbf{f}$ & $\%$ & \\
\hline \multirow{3}{*}{$\begin{array}{c}\text { Rekomendasi } \\
\text { (Word of mouth) } \\
\text { (Y21) }\end{array}$} & X111 & 14 & 17,00 & 53 & 65,00 & 15 & 18,00 & 0 & 0,00 & 0 & 0,00 & 3,99 \\
\hline & X112 & 20 & 24,00 & 46 & 59,00 & 14 & 17,00 & 0 & 0,00 & 0 & 0,00 & 4,07 \\
\hline & \multicolumn{11}{|c|}{ Rerata indikator word of mouth (Y21) } & 4,03 \\
\hline \multirow{3}{*}{$\begin{array}{c}\text { Kekebalan } \\
\text { (Reject another) } \\
\text { (Y22) }\end{array}$} & $\mathbf{X 1 2 1}$ & 9 & 11,00 & 40 & 49,00 & 27 & 33,00 & 5 & 6,00 & 0 & 0,00 & 3,63 \\
\hline & $\mathrm{X122}$ & 8 & 10,00 & 39 & 48,00 & 30 & 37,00 & 5 & 6,00 & 0 & 0,00 & 3,61 \\
\hline & \multicolumn{11}{|c|}{ Rerata indikator reject another (Y22) } & 3,62 \\
\hline \multirow{3}{*}{$\begin{array}{l}\text { Pembelian Ulang } \\
\text { (Repeat } \\
\text { purchasing) }\end{array}$} & $\mathrm{X} 131$ & 11 & 13,00 & 33 & 40,00 & 32 & 39,00 & 5 & 6,00 & 0 & 0,00 & 3,60 \\
\hline & $\mathbf{X 1 3 2}$ & 15 & 18,00 & 20 & 37,00 & 34 & 41,00 & 2 & 2,00 & 0 & 0,00 & 3,70 \\
\hline & \multicolumn{11}{|c|}{ Rerata indikator repeat purchasing (Y23) } & 3,65 \\
\hline \multicolumn{12}{|c|}{ Rerata variabel Loyalitas (Y2) } & 3,77 \\
\hline
\end{tabular}

Berdasarkan tabel diatas variabel Loyalitas ditunjukkan melalui indikator rekomendasi (word of mouth) dengan nilai rerata tanggapan responden sebesar $4,03 \%$, indicator rekomendasi dinyatakan dalam bentuk pernyataan bahwa pengguna smartphone samsung akan memberitahu hal-hal positif tentang produk yang digunakan kepada teman atu kerabat lainnya dengan nilai sebesar 4,07\%, indikator terendah yaitu kekebalan (reject another) dengan nilai rerata tanggapan responden sebesar 3,62\%, indikator kekebalan di nyatakan dalam bentuk pernyataan bahwa smartphone samsung merupakan produk smartphone terbaik dibandingkan dengan smartphone merek lainnya dengan nilai sebesar 3,65\%, terakhir yaitu indikator pembelian ulang (repeat purchasing) dengan nilai rerata tanggapan responden sebesar 3,70\%, indikator pembelian ulang dinyatakan dalam bentuk pernyataan bahwa pengguna akan lebih sering menggunakan produk merek smartphone merek samsung yang ditawarkan oleh perusahaan

\section{Pengujian Hipotesis}

a) Fisher-test

Pengujian ini dilakukan untuk mengetahui apakah semua variabel independen (endogen) mempunyai pengaruh yang sama terhadap variabel dependen (eksogen). Pengujian yang dilakukan menggunakan uji distribusi $\mathrm{F}$ caranya, yakni dengan membandingkan antara nilai kritis ( $\mathrm{f}_{\text {tabel }}$ ) dengan ( $\mathrm{f}_{\text {hitung }}$ ) yang terdapat pada tabel Analysis of Variance dari hasil perhitungan. Pada derajat signifikan 95\% $(\alpha=0,05)$ (Sugiyono, 2013) 
Tabel 6a. Hasil Uji-F

\begin{tabular}{|l|l|c|c|c|c|c|}
\hline \multicolumn{2}{|c|}{ Model } & $\begin{array}{c}\text { Sum of } \\
\text { Squares }\end{array}$ & Df & Mean Square & F & Sig. \\
\hline \multirow{2}{*}{1} & Regression & 2,989 & 1 & 2,989 & 19,517 &, $000^{\mathrm{b}}$ \\
\cline { 2 - 7 } & Residual & 12,252 & 80 &, 153 & & \\
\cline { 2 - 7 } & Total & 15,241 & 81 & & & \\
\hline \multicolumn{2}{|l}{ a. Dependent Variable: Kepuasan } \\
\hline
\end{tabular}

Dari tabel uji $\mathrm{F}$ tersebut dapat dirumuskan df1 = jumlah variabel (eksogen dan endogen) - variabel bebas dan df2 $=$ jumlah responden - jumlah variabel (dependen dan independen). Jadi, df1 $=2-1=1$ dan df2 $=82-2=80$. Maka $\mathrm{f}$ tabel diperoleh pada lampiran yaitu 4.18. Tebel tersebut menunjukkan bahwa hasil uji $\mathrm{F}$ yaitu $f$ hitung $>$ f tabel $(19,517 \geq 3,96$ ) dan nilai signifkan sebesar 0,000 . Hal ini berarti seluruh variabel endogen (dependen), yaitu variabel CRM (X) secara simultan memiliki pengaruh terhadap Kepuasan (Y1).

Tabel 6b. Hasil Uji-F

\begin{tabular}{|c|c|c|c|c|c|c|}
\hline \multicolumn{7}{|c|}{ ANOVAa $^{a}$} \\
\hline \multicolumn{2}{|r|}{ Model } & Sum of & Df & Mean & $\mathrm{F}$ & Sig. \\
\hline \multirow[t]{3}{*}{1} & Regression & 5,252 & 1 & 5,252 & 29,906 &, $000^{\mathrm{b}}$ \\
\hline & Residual & 14,049 & 80 &, 176 & & \\
\hline & Total & 19,300 & 81 & & & \\
\hline \multicolumn{7}{|c|}{ a. Dependent Variable: Loyalitas } \\
\hline \multicolumn{7}{|c|}{ b. Predictors: (Constant), Kepuasan } \\
\hline
\end{tabular}

Dari tabel 4.19 diatas uji $\mathrm{F}$ dapat dirumuskan df1 = jumlah variabel (eksogen dan endogen) - variabel bebas dan df2 $=$ jumlah responden - jumlah variabel (dependen dan independen). Jadi, df1 $=2-1=1$ dan df2 $=82-2=80$. Maka f tabel diperoleh pada lampiran yaitu 4.19. Tabel tersebut menunjukkan bahwa hasil uji $\mathrm{F}$ yaitu f hitung>ftabel $(29,906 \geq 3,96)$ dan nilai signifkan sebesar 0,000 . Hal ini berarti seluruh variabel endogen (dependen), yaitu Kepuasan (Y1) secara simultan memiliki pengaruh terhadap Loyalitas (Y2).

Tabel 6c. Hasil Uji-F

\begin{tabular}{|c|c|c|c|c|c|c|}
\hline \multicolumn{7}{|c|}{ ANOVAa $^{a}$} \\
\hline \multicolumn{2}{|c|}{ Model } & $\begin{array}{l}\text { Sum of } \\
\text { Squares }\end{array}$ & Df & $\begin{array}{c}\text { Mean } \\
\text { Square }\end{array}$ & $\mathrm{F}$ & Sig. \\
\hline \multirow[t]{3}{*}{1} & Regression & 5,252 & 2 & 2,626 & 14,768 &, $000^{\mathrm{b}}$ \\
\hline & Residual & 14,048 & 79 & ,178 & & \\
\hline & Total & 19,300 & 81 & & & \\
\hline \multicolumn{7}{|c|}{ a. Dependent Variable: Loyalitas } \\
\hline
\end{tabular}


Issue 3 (September, 2015)

Tabel tersebut menunjukkan bahwa hasil uji $F$ yaitu fhitung $>$ ftabel $(14,768 \geq 3,96)$ dan nilai signifkan sebesar 0,000 . Hal ini berarti seluruh variabel eksogen (independen), yaitu CRM (X), Kepuasan (Y1) secara simultan memiliki pengaruh terhadap Loyalitas (Y2).

\section{b) T-test}

Uji-t digunakan untuk mengetahui seberapa jauh pengaruh satu variabel penjelas secara individual dalam menerangkan variasi variabel terikat. Pengujian melauli uji $t$ adalah dengan $t_{\text {-hitung }}$ dan $t$-tabel pada derajat signifikasi $95 \%(\alpha=0,05)$ dengan pengujian dua sisi.

Tabel 7a. t-test

\begin{tabular}{|c|c|c|c|c|c|c|}
\hline \multicolumn{7}{|c|}{ Coefficients $^{\mathrm{a}}$} \\
\hline \multirow{2}{*}{\multicolumn{2}{|c|}{ Model }} & \multicolumn{2}{|c|}{$\begin{array}{l}\text { Unstandardized } \\
\text { Coefficients }\end{array}$} & \multirow{2}{*}{$\begin{array}{c}\begin{array}{c}\text { Standardized } \\
\text { Coefficients }\end{array} \\
\text { Beta } \\
\end{array}$} & \multirow[t]{2}{*}{$\mathrm{T}$} & \multirow[t]{2}{*}{ Sig. } \\
\hline & & B & Std. Error & & & \\
\hline \multirow[t]{2}{*}{1} & (Constant) & 2,439 & ,343 & & 7,107 & ,000 \\
\hline & CRM & ,410 & ,093 & ,443 & 4,418 & ,000 \\
\hline
\end{tabular}

Berdasarkan tabel diatas dapat dilihat yaitu pada nilai $\mathrm{t}$ dengan nilai $\mathrm{df}=\mathrm{n}$ $\mathrm{k}-1=82-1-1=80$. Pada tabel diatas menunjukkan hasil bahwa variabel CRM (X) dengan nilai $t$ hitung $\geq t$ tabel(4.418 $\geq 1.667)$ dan tingkat signifikan lebih kecil dari $0.05(0.000<0.05)$, yang berarti $\mathrm{H}_{\mathrm{a}}$ diterima sehingga dapat dikatakan bahwa CRM (X) berpengaruh signifikan secara parsial terhadap Kepuasan (Y1)

Tabel 7b. t-test

\begin{tabular}{|c|c|c|c|c|c|c|}
\hline \multicolumn{7}{|c|}{ Coefficients $^{a}$} \\
\hline & \multirow[t]{2}{*}{ Model } & \multicolumn{2}{|c|}{$\begin{array}{l}\text { Unstandardized } \\
\text { Coefficients }\end{array}$} & \multirow{2}{*}{$\begin{array}{c}\begin{array}{c}\text { Standardized } \\
\text { Coefficients }\end{array} \\
\text { Beta }\end{array}$} & \multirow[t]{2}{*}{$\mathrm{T}$} & \multirow[t]{2}{*}{ Sig. } \\
\hline & & B & Std. Error & & & \\
\hline \multirow{2}{*}{1} & (Constant) & 1,452 &, 426 & & 3,411 & ,001 \\
\hline & Kepuasan & ,587 & 107 & ,522 & 5,469 & ,000 \\
\hline
\end{tabular}

Berdasarkan tabel diatas dapat dilihat yaitu pada nilai $\mathrm{t}$ dengan nilai $\mathrm{df}=\mathrm{n}$ $\mathrm{k}-1=82-1-1=80$. Pada tabel diatas menunjukkan hasil bahwa variabel Kepuasan (Y1) dengan nilai $t_{\text {hitung }}$ lebih besar dari $t_{\text {tabel }}(5,469>1,667)$ dan tingkat signifikan lebih kecil dari $0.05(0.000<0.05)$, yang berarti $\mathrm{H}_{a}$ diterima sehingga dapat dikatakan bahwa Kepuasan berpengaruh signifikan secara parsial terhadap Loyalitas.

Tabel 7c. t-test

\begin{tabular}{|c|c|c|c|c|c|c|}
\hline \multicolumn{9}{|c|}{ Coefficients $^{\mathbf{a}}$} \\
\hline \multirow{2}{*}{ Model } & \multicolumn{2}{|c|}{$\begin{array}{c}\text { Unstandardized } \\
\text { Coefficients }\end{array}$} & $\begin{array}{c}\text { Standardized } \\
\text { Coefficients }\end{array}$ & \multirow{2}{*}{$\mathrm{T}$} & \multirow{2}{*}{ Sig. } \\
\cline { 3 - 5 } & B & Std. Error & Beta & & \\
\hline \multirow{3}{*}{1} & (Constant) & 1,461 &, 472 & & 3,094 &, 003 \\
\cline { 2 - 7 } & CRM &,- 005 &, 112 &,- 005 &,- 046 &, 964 \\
\cline { 2 - 6 } & Kepuasan &, 589 &, 120 &, 524 & 4,893 &, 000 \\
\hline
\end{tabular}


Issue 3 (September, 2015)

a. Dependent Variable: Loyalitas

Berdasarkan tabel diatas dapat dilihat yaitu pada nilai $\mathrm{t}$ dengan nilai $\mathrm{df}=\mathrm{n}-\mathrm{k}$ $1=82-2-1=79$, maka $t_{\text {tabel. }}$ Pada tabel diatas menunjukkan hasil bahwa variabel CRM dengan nilai $t_{\text {hitung }}$ lebih kecil dari $t_{\text {tabel }}(-0.046<1,667)$ dan tingkat signifikan lebih besar dari $0.05(0.964>0.05)$, yang berarti $\mathrm{H}_{\mathrm{a}}$ tidak diterima sehingga dapat dikatakan bahwa Customer Relationship Management (X) tidak berpengaruh signifikan secara parsial terhadap Loyalitas (Y2) dan variabel Kepuasan (Y1) dengan nilai $t_{\text {hitung }}>t_{\text {tabel }}(4,893>1.667)$ dan nilai signifikan lebih kecil dari $0.05(0.000<0.05)$, maka dapat disimpulkan bahwa $\mathrm{H}_{\mathrm{a}}$ diterima yang berarti Kepuasan berpengaruh signifikan secara parsial terhadap Loyalitas.

4. Interpretasi Hasil Penelitian

a. Pengaruh Customer Relationship Management (X) terhadap Kepuasan (Y1)

Berdasarkan analisis statistik inferensial dengan menggunakan analsisi jalur (path analysis) menyatakan bahwa terdapat pengaruh Customer Relationshp Management (X) terhadap kepuasan (Y1), sehingga hipotesis tersebut terbukti dan dapat diterima. Pengaruh tersebut signifikan, dengan demikian dengan adanya penerapan Customer Relationship Management (hubungan pelanggan) pada PT. Erafone akan dapat memberikan kepuasan terhadap konsumen dengan produk yang digunakan. Variabel Customer Relationship Management (X) merupakan variabel yang berpengaruh positif secara signifikan terhadap kepuasan (Y1) hal ini terbukti bahwa sig.t sebesar 0,000 dengan alpha $0,05(0,000<0,05)$

Hasil analisis deskriptif dari setiap item-item variabel Customer Relationship Management diperoleh rata-rata mean 3,94 yang berarti Customer Relationship Management (hubungan pelanggan) (X) pada PT. Erafone telah berjalan dengan baik. Dari nilai adjusted R Square 0,186 atau 18,6\%, artinya bahwa kepuasan (Y1) dipengaruhi sebesar 18,6\% oleh Customer Relationship Mangement (hubungan pelanggan). Sedangkan sisanya sebesar $81,4 \%$ dipengaruhi oleh variabel lain diluar variabel beba yang diteliti. Penelitian ini sejalan dengan penelitian yang dilakukan Sariyo U.P Bhaskara, Silvya L. Mandey. Olivia Nelwan (2014). Bahwa hasil penelitiannya menunjukkan bahwa CRM berpengaruh terhadap kepuasan konsumen

b. Pengaruh Customer Relationshp Management $(X)$ terhadap Loyalitas (Y2)

Berdasarkan analisis statistik inferensial dengan menggunakan analsisi jalur (path analysis) menyatakan bahwa tidak terdapat pengaruh Customer Relationshp Management (X) terhadap kepuasan (Y1), sehingga hipotesis tidak dapat diterima/ditolak. Pengaruh tersebut tidak signifikan, dengan demikian penerapan Customer Relationship Management (hubungan pelanggan ) pada PT. erafone belum dapat meningkatkan loyalitas konsumen/pengguna. Kesimpulan yang diperoleh bahwa Customer Relationship Management tidak berpengaruh signifikan terhadap loyalitas hal ini ditunjukkan bahwa alpha $0,05(0,964>0,05)$ berarti Ha ditolak.dan H0 dierima. Penelitian ini sejalan dengan penelitian yang dilakukan Dzikiryati Yuni Ersi dan Hatane Semuel (2014). CRM berpengaruh negatf tidak signifiksn terhadap loyalitas konsumen.

c. Pengaruh Kepuasan (Y1) terhadap Loyalitas (Y2)

Halaman 13

Author : Luli Yulianti (September, 2015). 01-13

https://dx.doi.org/10.17605/OSF.IO/DVB48 


\section{JURNAL ORGANISASI DAN MANAJEMEN}

Issue 3 (September, 2015)

Berdasarkan analisis statistik inferensial dengan menggunakan analsisi jalur (path analysis) menyatakan bahwa terdapat pengaruh antara Kepuasan (Y1) Terhadap Loyalitas (Y2) sehingga hipotesis tersebut terbukti dan dapat diterima. Pengaruh tersebut signifikan, dengan demikian dengan adanya kepuasan konsumen/pengguna yang tinggi akan dapat meningkatkan loyalitas konsumen/pengguna. Kesimpulan yang diperoleh bahwa Kepuasan berpengaruh signifikan terhadap loyalitas hal ini ditunjukkan bahwa alpha 0,05 $(0,000<0,05)$. Penelitian ini sejalan dengan penelitian yang dilakukan Dzikiryati Yuni Ersi dan Hatane Semuel (2014), bahwa kepuasan berpengaruh terhadap Loyalitas.

\section{Kesimpulan}

Penelitian ini bertujuan untuk mengetahui variabel mana sajakah yang mempunyai pengaruh pada Customer Relationship Management (hubungan pelanggan) dengan melalui Kepuasan Loyalitas. Penelitian ini yang berperan sebagai variabel bebas adalah variabel Customer Relationship Management (X) sedangkan variabel terikatnya adalah Kepuasan (Y1) dan Loyalitas (Y2). Responden penelitian ini berjumlah 82 responden. Berdasarkan hasil analisis dan pembahasan model hipotesis yang diajukan, maka dapat ditarik kesimpulan bahwa Variabel Customer Relationship Management (X) merupakan variabel yang berpengaruh secara signifikan terhadap kepuasan (Y1). Secara keseluruhan pelaksanaan customer relationship management yang telah dilakukan oleh perusahaan sudah dinilai baik oleh pelanggan. hal ini disebabkan karena pada indikator variabel CRM (X) yaitu pada indikator tekhnologi. Dengan adanya kemudahan pelanggan dalam memeproleh informasi tentang produk smartphone samsung melaui media elektronik/cetak dan online.

Variabel Customer Relationship Management (X) memberikan pengaruh yang tidak signifikan terhadap Loyalitas (Y2). Hal ini disebabkan karena pada indikator CRM (X) terdapat pengaruh kecil yaitu pada indikator proses. Dengan adanya kegiatan perusahaan dalam melakukan promosi baik secara langsung maupun tidak langsung maka pengguna akan semakin tertarik dalam melakukan pembelian. Hal ini berarti dalam meningkatkan loyalitas konsumen/pengguna, perusahaan harus melakukan kegiatan promosi.

Variabel kepuasan (Y1) merupakan variabel yang berpengaruh secara signifikan terhadap Loyalitas (Y2). Hal ini disebabkan karena pada indikator Kepuasan (Y1) terdapat pengaruh yang besar yaitu pada indikator Harapan ( Expectation ). Produk smartphone yang ditawarkan oleh perusahaan sudah memenuhi keinginan pelanggan/konsumen. Hal ini berarti pelanggan sudah merasa puas terhadap produk smartphone samsung yang ditawarkan oleh perusahaan sehingga meningkatkan loyalitas konsumen.

Diharapkan kepada Peneliti lanjutan untuk melakukan studi ini pada kontent yang berbeda dengan menambah variabel lain yang mempengaruhi loyalitas konsumen. Disarankan agar lebih memperhatikan waktu penelitian agar tingkat pengembalian (respon rate) kuesioner dapat lebih tinggi dan mendapat hasil yang lebih akurat.

\section{DAFTAR PUSATAKA}


Issue 3 (September, 2015)

Harjasiswi. D.P \& Yuliati. A.L. (2014). Pengaruh Bauran Pemasaran Terhadap Keputusan Pembelian Smartphone Samsung Berbasis Android. Jurnal Studi Manajemen \& Bisnis Vol.1 No. 2.

Jonathan Sarwono, (2007). Analisis Jalur untuk Riset Bisnis dengan SPSS, Yogyakarta : Andi Offset

Griffin, Jill. (2005). Customer Loyalty, Edisi Revisi, Jakarta : Erlangga Kotler (2000:429)

Sari, H. K. (2013). Efektivitas Loyalty Program dalam Customer Relationship Management terhadap Kepuasan dan Loyalitas Pelanggan (Studi Kegiatan Divisi Retensi dalam Pelaksanaan Loyalty Program â€ œIm3@ School Communityâ€ pada PT Indosat Tbk. Kantor Cabang Malang). Jurnal Ilmu Komunikasi, 6(2).

Kotler, Philip. \& Kevin Lane Keller, (2006), Marketing Management, Pearson Education Inc.

Kotler, Philip. (2007). Alih Bahasa Susanto, AB. Manajemen Pemasaran Indonesia. Buku 2. Jakarta: Salemba Empat

Tsiros, M., Mittal, V., \& Ross Jr, W. T. (2004). The role of attributions in customer satisfaction: A reexamination. Journal of consumer research, 31(2), 476-483.

Fandy Tjiptono. (2006). Manajemen Jasa. Edisi Pertama. Yogyakarta :

Imasari, Kartika, and Kezia Kurniawati Nursalin. (2011). Pengaruh Customer Relationship Management terhadap Loyalitas Pelanggan pada PT BCA Tbk." Fokus Ekonomi 10.3 (2011).

Bhaskara, S. U., Mandey, S. L., \& Nelwan, O. (2014). Customer relationship management $(\mathrm{crm})$ dan personal selling pengaruhnya terhadap kepuasan konsumen pada pt virgo ekspres tours \& travel manado. Jurnal Riset Ekonomi, Manajemen, Bisnis Dan Akuntansi, 2(1).

Gaffar F., Vanessa. (2007). CRM dan MPR Hotel. Bandung: Alfabeta.

Febrianingtyas, Media, Zainul Arifin \& Dahlan Fanani. (2014). Pengaruh Customer Relationship Management Terhadap Kepuasan Dan Loyalitas Nasabah (Survey Pada Nasabah Bank Jawa Timur Cabang Gedung Inbis Malang )". Jurnal Administrasi Bisnis (JAB).

Ersi, D. Y., \& Semuel, H. (2014). Analysis CRM, kepuasan pelanggan dan loyalitas produk UKM berbasis bahan baku terigu di Jawa Timur. Jurnal Manajemen Pemasaran, 8(1), 1-8.

Ramli, A. H., \& Sjahruddin, H. (2015). Building patient loyalty in healthcare services. International Review of Management and Business Research, 4(2), 391.

Wijaya, S., \& Thio, S. (2007). Implementasi membership card dan pengaruhnya dalam meningkatkan loyalitas pengunjung restoran di Surabaya. Fakultas Ekonomi Universitas risten Petra.

Febriyan, H., \& Sulistyowati, L. (2014). Pengaruh Customer Relationship Management (Crm) Terhadap Customer Trust Dan Customer Loyalty Pada Bank BRI Cabang Pekanbaru Imam Munandar. Jurnal Tepak Manajemen Bisnis, 6(3), 51-60.

Indah, Maulidiyah P. S. (2012) Analisis Atribut Produk Yang Dipertimbangkan Konsumen Dalam Membeli Handphone Merek Samsung Bersistem Android (Studi Kasus Pada Mahasiswa Universitas Pembangunan Nasional "Veteran" Jawa Timur). Undergraduate thesis, Faculty of Social Science and Political Science.

Halaman 15

Author : Luli Yulianti (September, 2015). 01-13

https://dx.doi.org/10.17605/OSF.IO/DVB48 